\title{
Nod Factor Perception During Infection Thread Growth Fine-Tunes Nodulation
}

\author{
Jeroen Den Herder, Celine Vanhee, Riet De Rycke, Viviana Corich, Marcelle Holsters, and \\ Sofie Goormachtig
}

Department of Plant Systems Biology, Flanders Interuniversity Institute for Biotechnology, Ghent University, B-9052 Gent, Belgium.

Submitted 12 April 2006. Accepted 5 September 2006.

\begin{abstract}
Bacterial nodulation factors (NFs) are essential signaling molecules for the initiation of a nitrogen-fixing symbiosis in legumes. NFs are perceived by the plant and trigger both local and distant responses, such as curling of root hairs and cortical cell divisions. In addition to their requirement at the start, NFs are produced by bacteria that reside within infection threads. To analyze the role of NFs at later infection stages, several phases of nodulation were studied by detailed light and electron microscopy after coinoculation of adventitious root primordia of Sesbania rostrata with a mixture of Azorhizobium caulinodans mutants ORS571-V44 and ORS571-X15. These mutants are deficient in NF production or surface polysaccharide synthesis, respectively, but they can complement each other, resulting in functional nodules occupied by ORS571-V44. The lack of NFs within the infection threads was confirmed by the absence of expression of an early NF-induced marker, leghemoglobin 6 of $S$. rostrata. NF production within the infection threads is shown to be necessary for proper infection thread growth and for synchronization of nodule formation with bacterial invasion. However, local production of NFs by bacteria that are taken up by the plant cells at the stage of bacteroid formation is not required for correct symbiosome development.
\end{abstract}

Nodules are root organs that are formed on legumes as a result of a symbiotic interaction with rhizobia. Nodule formation is plant controlled and consists of two processes, bacterial invasion and cortical cell division, which eventually merge when bacteria are released into the cells of the central tissue and fix atmospheric nitrogen.

In most legume species, rhizobial invasion starts with curling of root hairs. Bacteria are entrapped in this curl and, by local cell wall hydrolysis and invagination of the cellular membrane, an infection thread (IT) is formed that guides the bacteria toward the cells of the nodule primordium (Gage 2004). Upon reaching these cells, the bacteria are released in the plant cytoplasm as nitrogen-fixing organelles, surrounded by a plant-derived peri-

Corresponding author: M. Holsters; Telephone: 329 3313900; Fax: 329 3313809; E-mail: marcelle.holsters @ psb.ugent.be

Current address of Celine Vanhee: Departement Biotechnologie, Vrije Universiteit Brussel, Pleinlaan 2, B-1050 Brussels, Belgium.

Current address of Viviana Corich: Dipartimento di Biotecnologie Agrarie, Università di Padova, Agropolis, viale dell'Università 16, I-35020 Legnaro (PD), Italy.

Nucleotide sequence for SrLb6 has been deposited in the GenBank database under accession number DQ314613. bacteroid membrane (Brewin 2004). The aquatic legume Sesbania rostrata evolved an alternative strategy to allow rhizobial invasion, because ethylene, which accumulates during submergence, inhibits the root hair curling (RHC) process (Goormachtig et al. 2004a and b). On hydroponic roots, its microsymbiont Azorhizobium caulinodans directly enters the cortex at lateral root bases (LRBs) and induces the formation of infection pockets (IPs) by eliciting local plant cell death and by colonizing the resulting free spaces (D'Haeze et al. 2003). From the IPs, ITs are formed that guide the bacteria toward the cells of the nodule primordium. The same infection pathway is followed during nodulation of adventitious rootlets positioned on a vertical row along the stem of S. rostrata (Duhoux 1984; Tsien et al. 1983).

Perception of rhizobial signal molecules plays an essential role in the successful establishment of a nodule. Key bacterial nodulation signals are the nodulation factors (NFs), which are lipochitooligosaccharides decorated with various chemical groups at the reducing and nonreducing ends (D'Haeze and Holsters 2002). NFs induce responses at picomolar concentrations and are needed to initiate bacterial invasion as well as to trigger cortical cell division (Dénarié and Cullimore 1993; Heidstra and Bisseling 1996). Proper bacterial invasion also requires correct bacterial surface polysaccharides (SPS). Rhizobial mutants with defective SPS are hampered at various levels of the invasion process: some are inhibited at the level of IT initiation, whereas others have abnormal invasion patterns (Fraysse et al. 2003).

Perception and signaling of NFs have been central themes in legume research. Various plant mutants have been isolated that are defective in NF perception, and identification of the mutated genes has shown that NFs are most probably perceived by a family of receptor kinases that contain extracellular LysM domains (Arrighi et al. 2006; Limpens et al. 2003; Madsen et al. 2003; Radutoiu et al. 2003).

NFs are hydrophobic molecules that generally are believed to be unable to travel in plant tissues because they stick in cell walls, where they become immobilized (Goedhart et al. 1999, 2000). Hence, NFs trigger local responses in the plant cells that directly perceive them. They also provoke distant responses, which most probably are a consequence of NF-dependent secondary signals that move in plant tissues. Examples of local responses are root hair deformation, root hair-specific gene expression, and various cellular changes within the root hair, such as calcium spiking (Oldroyd and Downie 2004). Distant $\mathrm{NF}$ responses include formation of pre-infection threads (PITs), cortical and pericycle cell division, and nodulin gene expression (Heidstra and Bisseling 1996; van Brussel et al. 1992; Yang et al. 1994). 
NFs are still produced by bacteria within the ITs and their putative receptors are still expressed (Arrighi et al. 2006; D'Haeze et al. 1998; Schlaman et al. 1991; Sharma and Signer, 1990; Timmers et al. 1998; Van den Eede et al. 1992). Because NFs are indispensable to initiate nodulation, it is difficult to investigate their role in these cortical ITs. Complementation studies have shown that NFs can help rhizobia deficient in NF production to nodulate Vigna unguiculata, Glycine max, and Calopogonium caeruleum (Relić et al. 1994). The rhizobia enter the plant via RHC and nodules are formed in which the bacteria fix nitrogen, although to a lower extent than wild-type rhizobia. Similarly, an SPS-defective strain with a Tn5 insertion into a dTDP-D-glucose synthase gene of $A$. caulinodans, ORS571-X15, which is unable to invade the host and stays in superficially located IPs, can complement nodule formation of ORS571-V44, a strain with a Tn5 insertion into the nodA gene and deficient in NF production (D'Haeze et al. 1998; Goethals et al. 1994; Mergaert et al. 1993; Van den Eede et al. 1987). Mixed inoculation nodules are formed at a low frequency and are colonized by strain ORS571-V44, as demonstrated by plating crushed nodules on strain-selective medium and by using specific strains labeled with reporter constructs (D'Haeze et al. 1998). Hence, ORS571-X15 bacteria within the superficially located IPs serve as signaling centers that trigger distant NF responses and allow an NF-deficient strain to enter the plant and fix atmospheric nitrogen.

Mixed inoculation nodules did not develop like control nodules: the ORS571-V44 invasion was very much delayed compared with that of the wild-type and the nodules had a cauliflower-shaped structure instead of the regular spherical shape (D'Haeze et al. 1998). Therefore, we wondered whether perception of locally produced NFs in the cortical ITs might be needed to fine-tune the nodulation process and to synchronize rhizobial invasion with primordium formation. For that purpose, the development of mixed inoculation nodules was followed by light and electron microscopy. To demonstrate that NFdependent gene expression was not elicited during the invasion of ORS571-V44, in situ hybridizations were performed with an early leghemoglobin gene, which is induced by NFs and is expressed in cells neighboring the ITs. Our data indicate that the plant has to perceive NFs produced by bacteria within the ITs for proper IT development and progression.

\section{RESULTS}

\section{Light microscopic analysis}

of mixed inoculation nodule development.

To analyze the development of nodules generated after coinoculation of ORS571-V44 (NF deficient) and ORS571-X15 (SPS defective), stems were inoculated with a $1 / 1$ mixture of both strains and developing stem nodules were isolated at different timepoints for light microscopic analysis (discussed below).

In sections through developing adventitious root nodules 3 days postinoculation (dpi), a nodule primordium was seen in the mid-inner cortex and bacteria started to penetrate the cortical tissue. Bacterial colonization of the crack and small IPs could be detected (Fig. 1A, arrows). This developmental stage was similar to that of wild-type infection at 2 dpi (Fig. 1D), presumably because the SPS mutant ORS571-X15 grew more slowly and colonized the adventitious rootlets somewhat later. At $5 \mathrm{dpi}$, the development had not proceeded much further. The primordium was more pronounced and bacteria had migrated somewhat more deeply into the tissue, with enlarged, swollen ITs in the zone that is normally the infection center in the wild-type situation (Fig. 1B and C). The infection center is the central cortical zone characterized by cells through which transcellular ITs pass before they enter the nodule primordium. In comparison, during wild-type infection at $4 \mathrm{dpi}$, IPs were bigger and ITs guided the bacteria from the IPs toward the nodule primordium, which had already differentiated into a zonated structure with an apical meristem, an infection center, and an infection zone (Fig. 1E and F).

In the mixed inoculation situation at $8 \mathrm{dpi}$, the primordium started to zonate and a meristem could be distinguished at the apical part, followed by an infection zone-like region that was much broader than that of the wild type (Fig. 1G). Numerous IP-like structures were observed within the infection center (Fig. 1H, arrows) and the transcellular ITs were much thicker than those of the wild type. Internalization was not yet observed at this timepoint, in contrast to wild-type nodules that already had a large fixation zone at $6 \mathrm{dpi}$ (Fig. 1J and K).

The first infected cells were observed in the mixed inoculation nodules only from approximately $10 \mathrm{dpi}$ on. The release of the bacteria from ITs did not happen synchronously and still was observed even after $18 \mathrm{dpi}$, with infection sites distributed over the broad infection zone that almost completely surrounded the fixation zone (Fig. 1I, arrows). In contrast, during wildtype infection, a clear boundary of the fixation zone was seen without further infections (compare Fig. 1I, J, and L). Finally, with delay, most cells of the central tissue were infected, giving rise to a central tissue consisting of infected and uninfected cells that did not differ from central tissue of control nodules (D'Haeze et al. 1998; data not shown). Furthermore, newly formed nodule primordia were detected, even as late as $30 \mathrm{dpi}$, producing the cauliflower-shaped nodules at these late stages (data not shown).

To confirm that only ORS571-V44 invaded the nodules, coinoculations were done with one of both strains that carried plasmid pRG960SD-32, which enabled us to visualize the bacteria with a $\beta$-glucuronidase (GUS) assay (discussed below). The nodules were colonized by the ORS571-V44 strain that finally housed into the fixing cells of the nodules (Fig. 1I, M, and N). On the other hand, ORS571-X15 (pRG960SD-32) occurred at early stages in very superficially located IPs (Fig. 1O), as has been observed previously (D'Haeze et al. 1998). GUS staining was not seen in ITs or in the central tissue cells (data not shown).

\section{Transmission electron microscopy \\ of developing mixed inoculation nodules.}

The light microscopic analysis showed that growth of ITs was not completely blocked but that the threads were broader than in the wild-type situation and that deeper IP-like structures were present in the infection center. Transmission electron microscopy was performed for in-depth study of these phenomena. ITs were analyzed within the infection center and infection zone. The ITs were, indeed, much broader than the wild-type ITs, sometimes occupied a large portion of the plant cell (compare Fig. 2A, B, and C), and contained more matrix with fewer bacteria, whereas the cell wall of the threads was similar to that of the wild-type ITs. A layer of low electrondense material occurred at the IT wall (Fig. 2A and C, arrows). Moreover, the ITs were irregular in structure, with lots of bulges that often contained no bacteria (Fig. 2C, asterisk). At later stages, the ITs seemed to have problems traversing cells and consequently curled up, giving rise to a cell filled with ITs, but without bacterial release (Fig. 2D). These were the cells that looked like IPs in the infection center in light microscopy. However, no sign of cell death, characteristic of IP formation, could be detected.

Once the IT had reached the infection zone, the cell walls were hydrolyzed locally and an infection droplet was formed 
from which individual bacteria were released to form bacteroids (Fig 2E). The infection droplets as well as the infected cells in the fixation zone looked similar to those of the wild type (compare Fig. 2E and F, arrowheads).

\section{A leghemoglobin as an early marker for local NF perception during rhizobial invasion.}

By re-isolating bacteria from surface-sterilized, 10-day-old nodules, evidence was put forward that, indeed, only strain
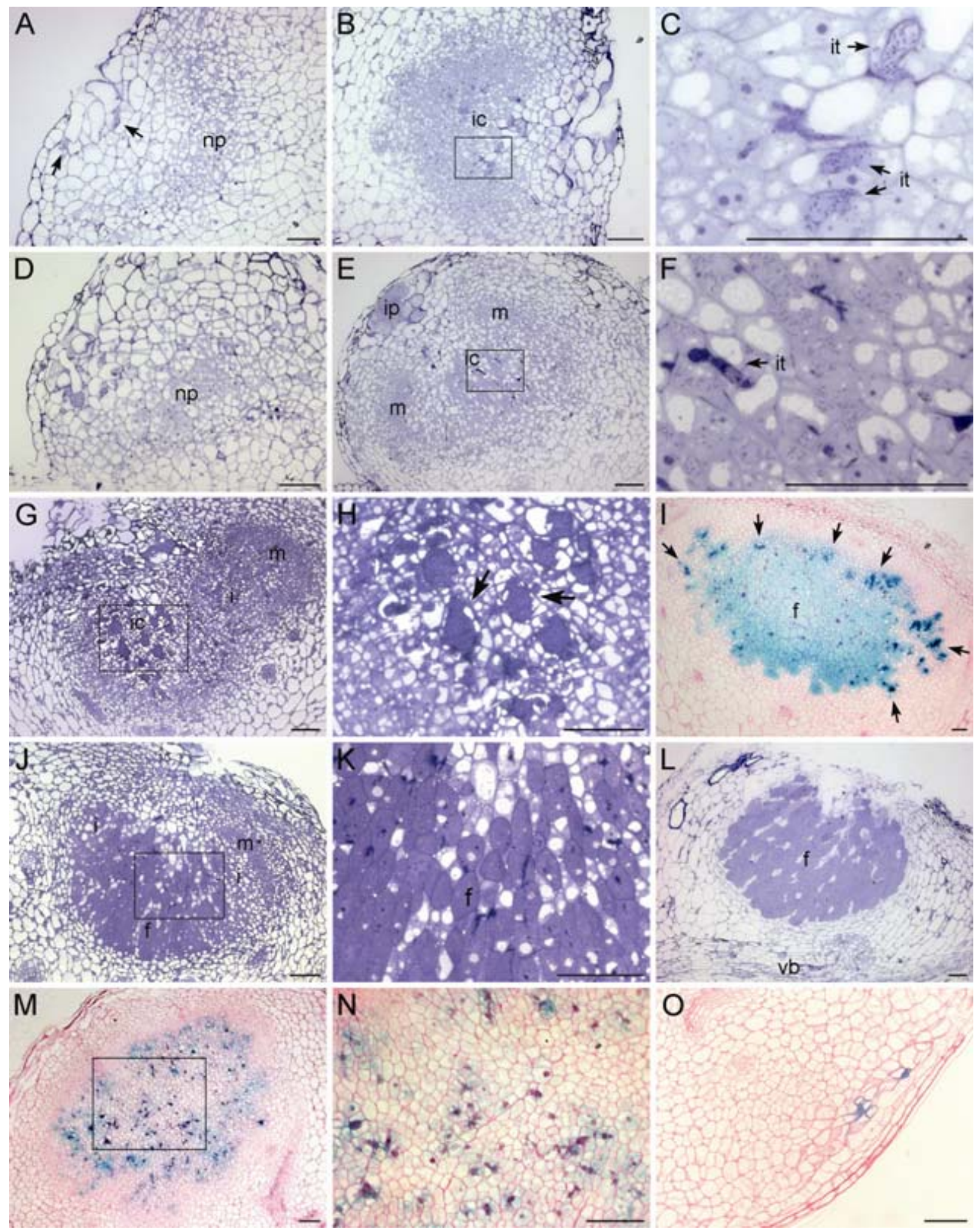

Fig. 1. Light microscopy of wild-type nodules versus developing nodules of ORS571-V44/ORS571-X15. Bright-field images of toluidine blue-stained semithin sections of developing mixed inoculation nodules at $\mathbf{A}, 3, \mathbf{B}$ and $\mathbf{C}, 5$, and $\mathbf{G}$ and $\mathbf{H}, 8$ days postinoculation (dpi). Developing wild-type nodules $\mathbf{D}$, 2, $\mathbf{E}$ and $\mathbf{F}, 4, \mathbf{J}$ and $\mathbf{K} 6$, and $\mathbf{L}, 10$ dpi. Ruthenium red-stained sections of developing mixed inoculation nodules with ORS571-V44 (nodulation factor deficient) containing the pRG960SD-32 plasmid at I, 18 and $\mathbf{M}$ and $\mathbf{N}, 11$ dpi. $\mathbf{O}$, Ruthenium red-stained section through a developing mixed inoculation nodule with the ORS571-X15 (pRG960SD-32) mutant (surface polysaccharide deficient) at $11 \mathrm{dpi}$. C, F, H, K, and N, Enlargements of the indicated area on the panel to the left. Abbreviations: f, fixation zone; i, infection zone; ic, infection center; ip, infection pocket; it, infection thread; m, meristem; np, nodule primordium; vb, vascular bundle. Bars $=100 \mu \mathrm{m}$. 
ORS571-V44 invaded the central tissue and that ORS571-X15 stayed in superficially located IPs (D'Haeze et al. 1998). To further demonstrate that ORS571-V44 did not carry NFs along during the invasion process, we used a molecular marker, whose expression depended on NFs produced locally within the ITs.

This $S$. rostrata marker, SrLb6, codes for a leghemoglobin (Strittmatter et al. 1989) and is upregulated early during $S$. rostrata adventitious root nodulation in a differential display experiment (Goormachtig et al. 1995). The originally published cDNA sequence (Strittmatter et al. 1989) was incomplete because it lacked the methionine start codon. The sequence was completed by rapid amplification of cDNA ends (RACE), adding $43 \mathrm{bp}$ to the $5^{\prime}$ side. RNA blot analysis confirmed the gene to be an early nodulin gene (Goormachtig et al. 1995). To investigate whether $S r L b 6$ expression is induced by NFs, roots were treated with $10^{-8} \mathrm{M}$ of purified $A$. caulinodans NFs and the expression was analyzed in samples at $30 \mathrm{~min}$ and $1,4,8,12,24$, and $48 \mathrm{~h}$ after treatment. SrLb6 expression levels were induced $4 \mathrm{~h}$ after treatment and increased to reach a maximum at $12 \mathrm{~h}$, after which they dropped again (Fig. 3A and B). Next, in situ hybridization was performed to localize $\mathrm{SrLb6}$ gene expression during different stages of nodulation. No transcripts could be visualized in uninfected root primordia (Fig. 3C and D). Two days after infection, cells around IPs and ITs were labeled intensively with silver precipitates that mark $S r L b 6$ expression (Fig. 3E and F). As the infection proceeded, the SrLb6 expression accompanied the front of ITs until deep in the infection center (Fig. 3G through J). Once the nodule primordium had differentiated in a zonated structure, the expression around these IPs and ITs decreased, while strong SrLb6 expression now could be seen in the infection zone (Fig. 3K and L) and, later, also at a lower level in the fixation zone (Fig. 3K through N). Because $S$. rostrata contains a family of leghemoglobin genes, all of which have not been sequenced, we cannot rule out that the SrLb6 probe might crosshybridize with another family member that is specifically expressed in the fixation zone. In conclusion, SrLb6 tran- scripts accumulate in tissues through which ITs pass and, hence, $S r L b 6$ might be directly induced by the NFs produced by the bacteria within the ITs.

\section{SrLb6 is not switched on during ORS571-V44 invasion in mixed inoculation nodules.}

To analyze whether SrLb6 was switched on during invasion of mixed inoculation nodules, in situ hybridization was performed on developing nodules at different stages after mixed inoculation. No early $S r L b 6$ expression could be seen during the progression of the ITs into the nodule tissues (Fig. 3O through R). On the other hand, once a zonated nodule was established, expression was detected again in the late infection zone and, to a lower extent, in the fixation zone (Fig. 3S through V). Developing wild-type nodules were included in parallel in the experiment and gave rise to the expression pattern described above (data not shown). Together, these data show that gene expression that depends on locally produced NFs is not switched on during the ORS571-V44 invasion of mixed inoculation nodules.

\section{DISCUSSION}

Rhizobial NFs are indispensable for legume nodulation. Upon detection by the plant, they trigger local responses in cells that directly perceive the NFs, thereby initiating RHC invasion, as well as distant responses that result in cortical cell division and the formation of PITs, paving the cortical path for IT passage. The distant responses supposedly are the result of secondary signals, because NFs cannot migrate into plant tissue and stick to plant cell walls (Goedhart et al. 1999, 2000). The genes responsible for NF production are still transcribed in bacteria that reside in ITs, indicating that these bacteria still produce NFs (D'Haeze et al. 1998; Schlaman et al. 1991; Sharma and Signer 1990; Van den Eede et al. 1992). Furthermore, bacterial NFs have been localized in ITs and in the cytoplasm of invaded plant cells in the infection zone (Timmers et al. 1998), suggesting a continuous role of NFs during growth and ramification of the ITs in the cortex.
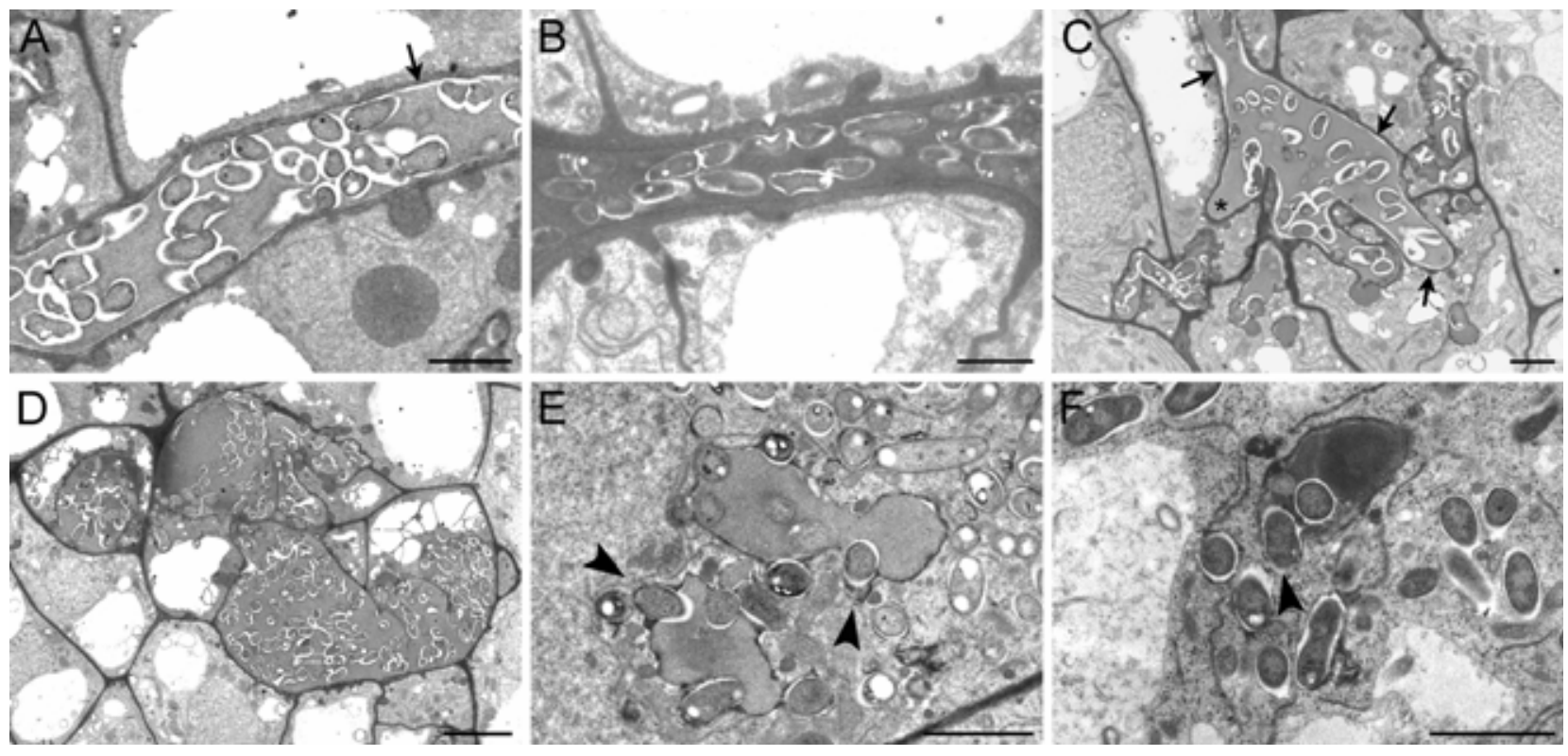

Fig. 2. Transmission electron microscopy images of infection threads (ITs) and bacterial uptake in wild-type and mixed inoculation nodules of Sesbania rostrata. A and B, IT formed after co-inoculation and wild-type infection, respectively. $\mathbf{C}$, Swollen IT in the infection center of mixed inoculation nodules at 5 days postinoculation. D, Infection pocket-like structure in the infection center 8 days after co-inoculation. $\mathbf{E}$ and $\mathbf{F}$, Infection droplet in a cell of the infection zone in a mixed inoculation and wild-type nodule, respectively. Arrows show low electron-dense material between IT wall and matrix; arrowheads indicate infection droplets. Bars: A through $\mathbf{C}, \mathbf{E}$, and F, $2 \mu \mathrm{m}$ and D, $5 \mu \mathrm{m}$. 


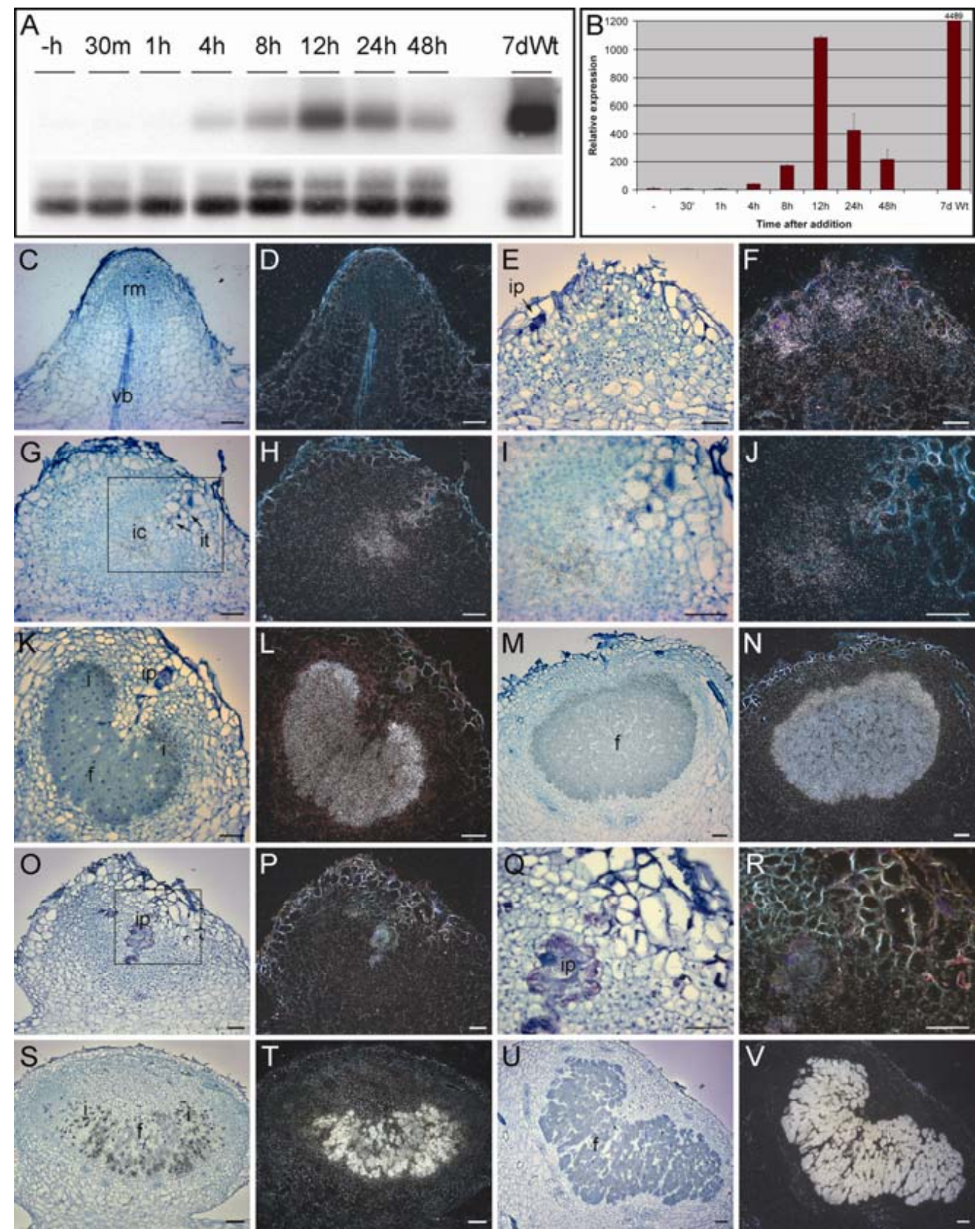

Fig. 3. SrLb6 expression analysis during wild-type and mixed inoculation nodule formation. A, SrLb6 transcript accumulation after nodulation factor addition to roots as determined by semi-quantitative reverse-transcription polymerase chain reaction analysis (upper panel) compared with the expression of the constitutive ubiquitin gene SrUbil (lower panel). As a positive control, roots with nodules were harvested at 7 days postinoculation with wild-type bacteria. B, Quantification of the $S r L b 6$ expression level after normalization against the constitutive ubiquitin gene expression level in each sample. In situ localization of $\operatorname{SrLb6}$ transcripts in longitudinal sections through $\mathbf{C}$ and $\mathbf{D}$, an uninoculated adventitious root primordium and through developing $\mathbf{E}$ and $\mathbf{F}, 2$-day-old, $\mathbf{G}$ and $\mathbf{H}$, detail $\mathbf{I}$ and $\mathbf{J}, 3$-day-old, $\mathbf{K}$ and $\mathbf{L}, 5$-day-old, and $\mathbf{M}$ and $\mathbf{N}$, 8-day-old stem nodules after inoculation with wild-type Azorhizobium caulinodans ORS571. In situ localization of SrLb6 in developing mixed inoculation nodules $\mathbf{O}$ and $\mathbf{P}$, detail $\mathbf{Q}$ and $\mathbf{R}, 6$ days, $\mathbf{S}$ and $\mathbf{T}, 9$ days, and $\mathbf{U}$ and $\mathbf{V}, 20$ days after co-inoculation with ORS571-X15 and ORS571-V44. Signal is seen as C, E, G, I, K, M, O, Q, S, and U, black spots in bright-field images and as D, F, H, J, $\mathbf{L}, \mathbf{N}, \mathbf{P}, \mathbf{R}, \mathbf{T}$, and $\mathbf{V}$, white spots in the corresponding dark-field pictures. Abbreviations: f, fixation zone; i, infection zone; ic, infection center; ip, infection pocket; it, infection thread; rm, root meristem; vb, vascular bundle. Bars: $\mathbf{A}$ through $\mathbf{R}, 100 \mu \mathrm{m}$ and $\mathbf{S}$ through $\mathbf{V}, 200 \mu \mathrm{m}$. 
To test this hypothesis, we made use of the LRB nodulation on $S$. rostrata, a nodule invasion way that skips the epidermis. The rhizobia enter the cortex directly via cracks at the LRBs and large cortical IPs are formed that are the functional equivalent of the microcolony within the curled root hair during RHC invasion (Goormachtig et al. 2004b). Infection with ORS571$\mathrm{X} 15$, a mutant strain with defective SPS, results in normal IP formation, whereas IT initiation is hampered. The rhizobia within the IPs produce NFs that trigger cell division. Hence, IPs filled with ORS571-X15 are NF signaling centers that are able to prepare the cortex for nodule formation and can complement a nodA mutant, ORS571-V44, to invade and occupy the central tissue (D'Haeze et al. 1998). Thus, study of the development of the mixed inoculation nodules might give insight into the function of NFs that are produced in the wild-type bacteria within the ITs.

To confirm the absence of NFs in the ITs of the mixed inoculation nodules, a marker gene was used that is induced upon NF treatment and that is expressed in plant cells containing ITs. The $S$. rostrata leghemoglobin $6, S r L b 6$, is early upregulated, well before the onset of nitrogen fixation (Goormachtig et al. 1995). Symbiotic leghemoglobin genes typically are expressed abundantly in the infected cells of nodules and are switched on when internalized bacteria start to fix atmospheric nitrogen. Recently, RNA interference (RNAi) of symbiotic leghemoglobins of Lotus japonicus proved their function in supplying oxygen to the respirating bacteria (Ott et al. 2005). However, early expression of leghemoglobins also has been described. In Vicia sativa, a screen for early markers for NF-induced genes resulted in the identification of a leghemoglobin gene, $V s L b 1$, that was induced $1 \mathrm{~h}$ after NF addition (Heidstra et al. 1997). Similarly, a leghemoglobin gene in L. japonicus was used as an early marker for NF-induced responses (Stracke et al. 2002). However, in neither case was the pattern of this early expression characterized further.

SrLb6 expression is induced from $4 \mathrm{~h}$ after NF application, and in situ hybridization during wild-type stem inoculation indicated that, in addition to typical expression in the fixation zone, the cells surrounding the IPs and ITs also induced early SrLb6 transcripts. Because no nitrogen fixation takes place in these cells, a function as oxygen carriers for the microsymbiont is improbable. Instead, the leghemoglobin might function as scavenger for NO, thereby controlling NO levels and subsequent plant defense reactions (Herold and Puppo 2005).

In the mixed inoculation nodules, the $S r L b 6$ expression pattern has changed. The early expression around IPs and ITs is no longer present, indicating that no NFs induce $S r L b 6$ expression. Occasionally, a minor expression around IPs has been observed, most probably because of the presence of NF-producing ORS571-X15 bacteria (data not shown). Interestingly, the later expression pattern in the late infection and fixation zones is still observed. In the central tissue, leghemoglobins are present only in the infected cells and not in the uninfected cells. Hence, induction of the genes might require bacterial presence and bacterial NF signaling (Heidstra et al. 1997). Our data show that bacteria unable to produce NFs can be internalized and that late leghemoglobin expression can still be triggered, implying that this gene expression is not activated by the NFs.

The absence of SrLb6 expression around the ITs in the mixed inoculation nodules provides additional evidence that no or very few ORS571-X15 bacteria are present along the IT track and that nodule formation is possible despite the production of NFs within the cortical ITs. To date, three different experiments have been performed to come to the same conclusion. First, crushed, mature, mixed inoculation nodules have been plated on strain-selective media; second, strains were used with GUS-reporter fusions; and, third, in situ hybridizations have been performed with NF-dependent genes (D'Haeze et al. 1998; this work). In neither experimental approach can it be completely ruled out that a small minority of ORS571-X15 bacteria would remain within the ITs. However, ORS571-X15 bacteria, if present at all, would not survive long because they are very sensitive to $\mathrm{H}_{2} \mathrm{O}_{2}$ that accumulates to a high level within the IPs and ITs of $S$. rostrata nodules (D'Haeze et al. 2004).

As a result of the absence of NFs during bacterial invasion within the cortex, ITs are shaped irregularly. They are thicker than those of the wild type, contain more matrix relative to bacteria, and show a rim of low electron-dense material between the wall and the matrix, often continuous with bacterial exopolysaccharides. The latter observation might be a consequence of a change in physicochemical properties of the matrix, such as its cross-linking status. A similar observation has been made during $A$. caulinodans invasion of $S$. rostrata SrSymRK knockdown plants (Capoen et al. 2005). SrSymRK and its homologs in Medicago spp., L. japonicus, and Pisum sativum (pea) have been shown to be involved in NF-dependent RHC invasion, in touch responses, and in bacterial uptake (Capoen et al. 2005; Endre et al. 2002; Esseling et al. 2004; Limpens et al. 2005; Stracke et al. 2002). Moreover, the gene is expressed along the invasion way in $S$. rostrata and in the infection zone of $S$. rostrata and Medicago truncatula (Capoen et al. 2005; Limpens et al. 2005). Thus, the similarity in IT structure might indicate that $S r S y m R K$ is involved in NF signaling within the cortical cells through which ITs proceed.

In addition to their irregular structure, the ITs also have problems in penetrating deeper tissues and proceeding to the next cells. In the infection center, IP-like structures have been observed. Electron microscopy demonstrated that these structures consist of plant cells with curled ITs, which is a consequence of a hampered IT growth without progression to deeper cell layers. Adding pure NFs to plants results in the formation of PITs in the outer cortical cells through which ITs would pass (Yang et al. 1994). Our results indicate that distant NF signaling is not enough for proper IT penetration and progression, and that local NF signaling within the ITs is needed continuously for proper penetration. Some plant mutants have been described that inhibit IT penetration, such as $M$. truncatula ritl and bitl. When inoculated, these mutants induce small bumps on the root surface and ITs abort in the epidermis or outer cortex (Mitra and Long 2004). Whether these plant genes are involved in cortical NF perception or signaling awaits further characterization.

Later during development, the switch from nodule primordium to a developing nodule with the typical zonation of indeterminate nodules also takes place in mixed inoculation nodules, indicating that local NFs are not needed to induce this switch and to establish the nodule meristem. Once the zonated structure is established, an irregular development of the central tissue is observed. The infection zone, which usually constitutes only a few cell layers, is highly enlarged. Moreover, the bacterial uptake that normally results in a sharp border between the infection zone and fixation zone happens in an unsynchronized fashion because bacterial uptake is seen in cells spread over the infection zone, with large zones of uninfected cells in between that only become infected later. These results demonstrate that continuous production of the NFs by bacteria within the ITs in the cortex and infection zone is needed to synchronize the nodule development that consists of two developmental programs, cell division and bacterial infection, coming together at the stage where the newly formed cells take up bacteria. Thus, continuous NF production is needed to keep the two processes in harmony. 
The final purpose of nodule formation, the internalization of the bacteria, is not hampered when NFs are not produced. Infection droplets are formed and plant cells eventually are completely filled with differentiated bacteroids with a normal appearance. Consequently, the signals for bacterial uptake are not the NFs. Signals other than NFs have been suggested to be essential for endosymbiosis (Verma and Hong 1996). These factors most probably also are not bacterial lipopolysaccharides (LPS), because several LPS mutants could be internalized (Campbell et al. 2002; Mathis et al. 2005; Niehaus et al. 1998; Perotto et al. 1994).

Because a family of LysM-containing receptor-like kinases perceives NFs in the epidermis (Ben Amor et al. 2003; Madsen et al. 2003; Radutoiu et al. 2003), the question must be raised whether these receptors also are involved in cortical perception of the NFs. However, this is difficult to predict, because most of the mutants show completely no response to the bacteria or their NFs or block IT growth in the epidermis. On the other hand, because pea sym10 is expressed at a higher level in tissues that contain growing ITs (Madsen et al. 2003) and $M$. truncatula NFP and LYK3 transcripts are localized along the IT track and within the infection zone, respectively (Arrighi et al. 2006; Limpens et al. 2003), these receptors possibly are also involved in NF perception downstream of the epidermis. Functional study of the orthologous gene in $S$. rostrata during LRB nodulation, which overcomes the epidermis, might give some insight into this aspect.

In conclusion, we have shown that NF-deficient azorhizobia are able to invade $S$. rostrata roots provided that NFs are present at the outside for distant signaling. Eventually, the mutant bacteria will internalize and initiate nitrogen fixation. However, continuous NF production by bacteria within the ITs is needed to allow efficient invasion and synchronization of nodule development and bacterial infection. We also have demonstrated that NFs are not needed locally for bacterial uptake. The signals derived from plants or bacteria that control the bacterial uptake are not known and it remains a big challenge to unravel this important step in symbiotic nitrogen fixation.

\section{MATERIALS AND METHODS}

\section{Bacterial strains and growth conditions.}

A. caulinodans ORS571, ORS571-X15 (Goethals et al. 1994), ORS571-X15 (pRG960SD-32) (D'Haeze et al. 1998), ORS571-V44 (Van den Eede et al. 1987), and ORS571-V44 (pRG960SD-32) (D'Haeze et al. 1998) were grown at $37^{\circ} \mathrm{C}$ in yeast extract broth medium (Geremia et al. 1994) containing the appropriate antibiotics.

Escherichia coli strains were grown at $37^{\circ} \mathrm{C}$ in Luria Bertani medium (Sambrook et al. 1989). Antibiotics were applied in the following concentrations for $A$. caulinodans and $E$. coli strains: carbenicillin at $100 \mu \mathrm{g} / \mathrm{ml}$, kanamycin at $50 \mu \mathrm{g} / \mathrm{ml}$, and spectinomycin at $100 \mu \mathrm{g} / \mathrm{ml}$.

\section{Plant growth and inoculation.}

$S$. rostrata Brem seeds were surface sterilized (Goethals et al. 1989), germinated, and grown at $28^{\circ} \mathrm{C}$ under a regime of 16 $\mathrm{h}$ of light and $8 \mathrm{~h}$ of darkness (Goormachtig et al. 1995). For stem inoculations, three plants were cultivated per pot and, after 6 weeks, stems were inoculated with azorhizobia as described (Goormachtig et al. 1995). For mixed inoculations with ORS571-X15 and ORS571-V44, both strains were grown to an identical optical density measured at $600 \mathrm{~nm}$ and were mixed at equal volumes. Stems were inoculated by painting with this mixed bacterial suspension.

For root inoculation, seedlings were transferred to $70-\mathrm{ml}$ tubes containing sterile nitrogen-free Norris medium, $\mathrm{pH} 7.0$
(Vincent 1970), and inoculated after 1 week as described (Fernández-López et al. 1998). Purified NFs were obtained as described and added at a final concentration of $10^{-8} \mathrm{M}\left(5 \times 10^{-9}\right.$ $\mathrm{M}$ of each fraction $\mathrm{pI}$ and $\mathrm{pII}$ ) (Mergaert et al. 1993).

\section{Isolation of the full-length cDNA clone.}

RACE was performed with the SMART RACE cDNA amplification kit (Clontech, Palo Alto, CA, U.S.A.) to obtain the additional 5' part of the sequence. cDNA was synthesized from mixed RNA extracted from root primordia at different timepoints after inoculation with $A$. caulinodans ORS571. The antisense primers Lb6-as2 (5'-ATTTATGCCTTTATGGCAATAT G-3') and Lb6Race5' (5'-ATTGCTCAACTCATCGCTCC-3') combined with the primers UPM (5'-CTAATACGACTCAC TATAGGGCAAGCAGTGGTATCAACGCAGAGT-3') and NUP (5'-AAGCAGTGGTATCAACGCAGAG-3'), respectively, were used for successive nested amplification steps according to the manufacturer's instructions (Clontech). The complete open reading frame was reconstructed by polymerase chain reaction (PCR) amplification with primers Lb6flSense (5'-GG CATTGAGAATACAGAT AACAA-3') and Lb6-as2 with the Advantage 2 Polymerase Mix (Clontech). The 558-bp PCR fragment was cloned in the pCRII-Topo cloning vector (Invitrogen, Carlsbad, CA, U.S.A.) and designated SrLb6fl\#23. DNA was sequenced with universal SP6 and T7 primers. Sequence data were assembled and analyzed with the GCG Wisconsin Package (Accelrys, San Diego, CA, U.S.A.).

\section{RNA analysis.}

RNA of roots was prepared according to Kiefer and associates (2000) and semiquantitative reverse-transcription (RT)-PCR analysis was performed as described by Corich and associates (1998). For the specific amplification of a 235-bp fragment of SrLb6, sense primer Lb6-s1 (5'-CCTGTTCATGTTCAGAAA GG-3') and antisense primer Lb6-as2 were used. As a constitutive control, a ubiquitin fragment was amplified with sense primer ubi14 (5'-GATTTTTGTGAAGACCTTGACGGG-3') and antisense primer ubil6 (5'-CACAGACCCATTACACATC CACAAG-3'). The program consisted of 25 or 20 cycles, respectively, of amplification for $30 \mathrm{~s}$ at $94^{\circ} \mathrm{C}, 30 \mathrm{~s}$ at $53^{\circ} \mathrm{C}$, and $30 \mathrm{~s}$ at $72^{\circ} \mathrm{C}$. PCR products were detected by autoradiography after blotting to a Hybond-N nylon membrane (GE-Healthcare, Little Chalfont, U.K.) as described (Corich et al. 1998). Probes were generated from the purified PCR product with the Rediprime II Random Prime Labeling System (GE-Healthcare) and the membranes were analyzed with a PhosphorImager (GE-Healthcare). RT-PCR analysis was repeated twice and results were quantified to the constitutive control with ImageQuant software (GE-Healthcare).

\section{Light and electron microscopy.}

Wild-type developing nodules and mixed inoculation nodules were harvested at different timepoints after inoculation and treated for light and electron microscopy (D'Haeze et al. 1998). Samples in which one of the mutants contained the pRG960SD-32 plasmid first were stained for GUS (D'Haeze et al. 1998). The material was fixed by a mixture of $4 \%$ formaldehyde and $3 \%$ glutaraldehyde in $0.1 \mathrm{M}$ sodium-cacodylate buffer $(\mathrm{pH} 7.2)$, post-fixed with $2 \%$ ( $\mathrm{vol} / \mathrm{vol}) \mathrm{OsO}_{4}$ and $1.5 \%$ (wt/vol) $\mathrm{K}_{3} \mathrm{Fe}(\mathrm{CN})_{6}$ in the cacodylate buffer, dehydrated, stained with $1 \%$ uranyl acetate, and embedded in Spurr's resin. Semithin sections of $1 \mu \mathrm{m}$ were stained with $0.5 \%$ toluidine blue or $0.1 \%$ ruthenium red, mounted with Depex (SigmaAldrich, St. Louis), and examined under a bright-field microscope DMBL (Leica, Wetzlar, Germany). Images were taken with an Axiocam digital camera (Zeiss, Jena, Germany) and processed with corresponding software (Axiovision; Zeiss). 
Ultrathin sections of $60 \mathrm{~nm}$, made on an Ultracut E microtome (Reichert-Jung, Nussloch, Germany), were post-stained in an ultrostainer (Leica) with uranyl acetate and lead citrate. The sections were further examined with a transmission electron microscope 1010 (JEOL, Tokyo).

\section{In situ hybridization.}

Sections of $10 \mu \mathrm{m}$ of paraffin-embedded developing stem nodules were hybridized in situ as described (Goormachtig et al. 1997). ${ }^{35} \mathrm{~S}$-labeled antisense probes were produced according to standard procedures (Sambrook et al. 1989). Plasmid pT7GW-Lb6 was digested with NcoI to yield a template for radioactive probe production with SP6 RNA polymerase (Invitrogen). Sections of wild-type inoculations were hybridized simultaneously with the same RNA probe and the procedure was done twice.

\section{ACKNOWLEDGMENTS}

This work was supported by grants from the Interuniversity Poles of Attraction Programme-Belgian Science Policy (P5/13). J. Den Herder is a Research Fellow of the Research Foundation-Flanders. The authors thank $\mathrm{M}$. De Cock for help in preparing the manuscript.

\section{LITERATURE CITED}

Arrighi, J.-F., Barre, A., Ben Amor, B., Bersoult, A., Campos Soriano, L., Mirabella, R., de Carvalho-Niebel, F., Journet, E.-P., Ghérardi, M., Huguet, T., Geurts, R., Dénarié, J., Rougé, P., and Gough, C. The Medicago truncatula lysine motif-receptor-like kinase gene family includes NFP and new nodule-expressed genes. Plant Physiol. 142:265-279.

Ben Amor, B., Shaw, S.L., Oldroyd, G. E. D., Maillet, F., Penmetsa, R. V., Cook, D., Long, S. R., Dénarié, J., and Gough, C. 2003. The NFP locus of Medicago truncatula controls an early step of Nod factor signal transduction upstream of a rapid calcium flux and root hair deformation. Plant J. 34:495-506.

Brewin, N. J. 2004. Plant cell wall remodeling in the Rhizobium-legume symbiosis. Crit. Rev. Plant Sci. 23:293-316.

Campbell, G. R. O., Reuhs, B. L., and Walker, G. C. 2002. Chronic intracellular infection of alfalfa nodules by Sinorhizobium meliloti requires correct lipopolysaccharide core. Proc. Natl. Acad. Sci. U.S.A. 99:39383943.

Capoen, W., Goormachtig, S., De Rycke, R., Schroeyers, K., and Holsters, M. 2005. SrSymRK, a plant receptor essential for symbiosome formation. Proc. Natl. Acad. Sci. U.S.A. 102:10369-10374.

Corich, V., Goormachtig, S., Lievens, S., Van Montagu, M., and Holsters, M. 1998. Patterns of ENOD40 gene expression in stem-borne nodules of Sesbania rostrata. Plant Mol. Biol. 37:67-76.

Dénarié, J., and Cullimore, J. 1993. Lipo-oligosaccharide nodulation factors: A new class of signaling molecules mediating recognition and morphogenesis. Cell 74:951-954.

D'Haeze, W., and Holsters, M. 2002. Nod factor structures, responses, and perception during initiation of nodule development. Glycobiology 12:79R-105R.

D'Haeze, W., Gao, M., De Rycke, R., Van Montagu, M., Engler, G., and Holsters, M. 1998. Roles for azorhizobial Nod factors and surface polysaccharides in intercellular invasion and nodule penetration, respectively. Mol. Plant-Microbe Interact. 11:999-1008.

D'Haeze, W., De Rycke, R., Mathis, R., Goormachtig, S., Pagnotta, S., Verplancke, C., Capoen, W., and Holsters, M. 2003. Reactive oxygen species and ethylene play a positive role in lateral root base nodulation of a semiaquatic legume. Proc. Natl. Acad. Sci. U.S.A. 100:1178911794.

D’Haeze, W., Glushka, J., De Rycke, R., Holsters, M., and Carlson, R. W. 2004. Structural characterization of extracellular polysaccharides of Azorhizobium caulinodans and importance for nodule initiation on Sesbania rostrata. Mol. Microbiol. 52:485-500.

Duhoux, E. 1984. Ontogénèse des nodules caulinaires du Sesbania rostrata (légumineuses). Can. J. Bot. 62:982-994.

Endre, G., Kereszt, A., Kevei, Z., Mihacea, S., Kaló, P., and Kiss, G. B. 2002. A receptor kinase gene regulating symbiotic nodule development. Nature 417:962-966.

Esseling, J. J., Lhuissier, F. G. P., and Emons, A. M. C. 2004. A nonsymbiotic root hair tip growth phenotype in NORK-mutated legumes: Implications for nodulation factor-induced signaling and formation of a multifaceted root hair pocket for bacteria. Plant Cell 16:933-944.
Fernández-López, M., Goormachtig, S., Gao, M., D’Haeze, W., Van Montagu, M., and Holsters, M. 1998. Ethylene-mediated phenotypic plasticity in root nodule development on Sesbania rostrata. Proc. Natl. Acad. Sci. U.S.A. 95:12724-12728.

Fraysse, N., Couderc, F., and Poinsot, V. 2003. Surface polysaccharide involvement in establishing the rhizobium-legume symbiosis. Eur. J. Biochem. 270:1365-1380.

Gage, D. J. 2004. Infection and invasion of roots by symbiotic, nitrogenfixing rhizobia during nodulation of temperate legumes. Microbiol. Mol. Biol. Rev. 68:280-300.

Geremia, R. A., Mergaert, P., Geelen, D., Van Montagu, M., and Holsters, M. 1994. The NodC protein of Azorhizobium caulinodans is an $N$-acetylglucosaminyltransferase. Proc. Natl. Acad. Sci. U.S.A. 91:26692673.

Goedhart, J., Hink, M. A., Visser, A. J. W. G., Bisseling, T., and Gadella Jr., T. W. J. 2000. In vivo fluorescence correlation microscopy (FCM) reveals accumulation and immobilization of Nod factors in root hair cell walls. Plant J. 21:109-119.

Goedhart, J., Röhrig, H., Hink, M. A., van Hoek, A., Visser, A. J. W. G., Bisseling, T., and Gadella Jr., T. W. J. 1999. Nod factors integrate spontaneously in biomembranes and transfer rapidly between membranes and to root hairs, but transbilayer flip-flop does not occur. Biochemistry 38:10898-10907.

Goethals, K., Gao, M., Tomekpe, K., Van Montagu, M., and Holsters, M. 1989. Common nodABC genes in Nod locus 1 of Azorhizobium caulinodans: Nucleotide sequence and plant-inducible expression. Mol. Gen. Genet. 219:289-298.

Goethals, K., Leyman, B., Van den Eede, G., Van Montagu, M., and Holsters, M. 1994. An Azorhizobium caulinodans ORS571 locus involved in lipopolysaccharide production and nodule formation on Sesbania rostrata stems and roots. J. Bacteriol. 176:92-99.

Goormachtig, S., Alves-Ferreira, M., Van Montagu, M., Engler, G., and Holsters, M. 1997. Expression of cell cycle genes during Sesbania rostrata stem nodule development. Mol. Plant-Microbe Interact. 10:316325.

Goormachtig, S., Capoen, W., and Holsters, M. 2004a. Rhizobium infection: Lessons from the versatile nodulation behaviour of water-tolerant legumes. Trends Plant Sci. 9:518-522.

Goormachtig, S., Capoen, W., James, E. K., and Holsters, M. 2004b. Switch from intracellular to intercellular invasion during water stresstolerant legume nodulation. Proc. Natl. Acad. Sci. U.S.A. 101:63036308.

Goormachtig, S., Valerio-Lepiniec, M., Szczyglowski, K., Van Montagu, M., Holsters, M., and de Bruijn, F. J. 1995. Use of differential display to identify novel Sesbania rostrata genes enhanced by Azorhizobium caulinodans infection. Mol. Plant-Microbe Interact. 8:816-824.

Heidstra, R., and Bisseling, T. 1996. Nod factor-induced host responses and mechanisms of Nod factor perception. New Phytol. 133:25-43.

Heidstra, R., Nilsen, G., Martinez-Abarca, F., van Kammen, A., and Bisseling, T. 1997. Nod factor-induced expression of leghemoglobin to study the mechanism of $\mathrm{NH}_{4} \mathrm{NO}_{3}$ inhibition on root hair deformation. Mol. Plant-Microbe Interact. 10:215-220.

Herold, S., and Puppo, A. 2005. Oxyleghemoglobin scavenges nitrogen monoxide and peroxynitrite: A possible role in functioning nodules? J. Biol. Inorg. Chem. 10:935-945.

Kiefer, E., Heller, W., and Ernst, D. 2000. A simple and efficient protocol for isolation of functional RNA from plant tissues rich in secondary metabolites. Plant Mol. Biol. Rep. 18:33-39.

Limpens, E., Franken, C., Smit, P., Willemse, J., Bisseling, T., and Geurts, R. 2003. LysM domain receptor kinases regulating rhizobial Nod factorinduced infection. Science 302:630-633.

Limpens, E., Mirabella, R., Fedorova, E., Franken, C., Franssen, H., Bisseling, T., and Geurts, R. 2005. Formation of organelle-like $\mathrm{N}_{2}$-fixing symbiosomes in legume root nodules is controlled by $D M I 2$. Proc. Natl. Acad. Sci. U.S.A. 102:10375-10380.

Madsen, E. B., Madsen, L. H., Radutoiu, S., Olbryt, M., Rakwalska, M., Szczyglowski, K., Sato, S., Kaneko, T., Tabata, S., Sandal, N., and Stougaard, J. 2003. A receptor kinase gene of the LysM type is involved in legume perception in rhizobial signals. Nature 425:637-640.

Mathis, R., Van Gijsegem, F., De Rycke, R., D’Haeze, W., Van Maelsaeke, E., Anthonio, E., Van Montagu, M., Holsters, M., and Vereecke, D. 2005. Lipopolysaccharides as a communication signal for progression of legume endosymbiosis. Proc. Natl. Acad. Sci. U.S.A. 102:26552660.

Mergaert, P., Van Montagu, M., Promé, J.-C., and Holsters, M. 1993. Three unusual modifications, a D-arabinosyl, an $N$-methyl, and a carbamoyl group, are present on the Nod factors of Azorhizobium caulinodans strain ORS571. Proc. Natl. Acad. Sci. U.S.A. 90:1551-1555.

Mitra, R. M., and Long, S. R. 2004. Plant and bacterial symbiotic mutants define three transcriptionally distinct stages in the development of the 
Medicago truncatula/Sinorhizobium meliloti symbiosis. Plant Physiol. 134:595-604

Niehaus, K., Lagares, A., and Pühler, A. 1998. A Sinorhizobium meliloti lipopolysaccharide mutant induces effective nodules on the host plant Medicago sativa (alfalfa) but fails to establish a symbiosis with Medicago truncatula. Mol. Plant-Microbe Interact. 11:906-914.

Oldroyd, G. E. D., and Downie, J. A. 2004. Calcium, kinases and nodulation signaling in legumes. Nat. Rev. Mol. Cell Biol. 5:566-576.

Ott, T., van Dongen, J. T., Günther, C., Krusell, L., Desbrosses, G., Vigeolas, H., Bock, V., Czechowski, T., Geigenberger, P., and Udvardi, M. K. 2005. Symbiotic leghemoglobins are crucial for nitrogen fixation in legume root nodules but not for general plant growth and development. Curr. Biol. 15:531-535.

Perotto, S., Brewin, N. J., and Kannenberg, E. L. 1994. Cytological evidence for a host defense response that reduces cell and tissue invasion in pea nodules by lipopolysaccharide-defective mutants of Rhizobium leguminosarum strain 3841. Mol. Plant-Microbe Interact. 7:99-112.

Radutoiu, S., Madsen, L. H., Madsen, E. B., Felle, H. H., Umehara, Y. Grønlund, M., Sato, S., Nakamura, Y., Tabata, S., Sandal, N., and Stougaard, J. 2003. Plant recognition of symbiotic bacteria requires two LysM receptor-like kinases. Nature 425:585-592.

Relić, B., Perret, X., Estrada-García, M. T., Kopcinska, J., Golinowski, W., Krishnan, H. B., Pueppke, S. G., and Broughton, W. J. 1994. Nod factors of Rhizobium are a key to the legume door. Mol. Microbiol. 13:171-178.

Sambrook, J., Fritsch, E. F., and Maniatis, T. 1989. Molecular Cloning, A Laboratory Manual, 2nd ed. Cold Spring Harbor Laboratory Press, Cold Spring Harbor, NY, U.S.A.

Schlaman, H. R. M., Horvath, B., Vijgenboom, E., Okker, R. J. H., and Lugtenberg, B. J. J. 1991. Suppression of nodulation gene expression in bacteroids of Rhizobium leguminosarum biovar viciae. J. Bacteriol. 173:4277-4287.

Sharma, S. B., and Signer, E. R. 1990. Temporal and spatial regulation of the symbiotic genes of Rhizobium meliloti in planta revealed by transposon Tn5-gusA. Genes Dev. 4:344-356.

Stracke, S., Kistner, C., Yoshida, S., Mulder, L., Sato, S., Kaneko, T.,
Tabata, S., Sandal, N., Stougaard, J., Szczyglowski, K., and Parniske, M. 2002. A plant receptor-like kinase required for both bacterial and fungal symbiosis. Nature 417:959-962.

Strittmatter, G., Chia, T.-F., Trinh, T. H., Katagiri, F., Kuhlemeier, C., and Chua, N.-H. 1989. Characterization of nodule-specific cDNA clones from Sesbania rostrata and expression of the corresponding genes during the initial stages of stem nodules and root nodules formation. Mol. Plant-Microbe Interact. 2:122-127.

Timmers, A. C. J., Auriac, M.-C., de Billy, F., and Truchet, G. 1998. Nod factor internalization and microtubular cytoskeleton changes occur concomitantly during nodule differentiation in alfalfa. Development 125:339-349.

Tsien, H. C., Dreyfus, B. L., and Schmidt, E. L. 1983. Initial stages in the morphogenesis of nitrogen-fixing stem nodules of Sesbania rostrata. J. Bacteriol. 156:888-897.

van Brussel, A. A. N., Bakhuizen, R., van Spronsen, P. C., Spaink, H. P. Tak, T., Lugtenberg, B. J. J., and Kijne, J. W. 1992. Induction of preinfection thread structures in the leguminous host plant by mitogenic lipo-oligosaccharides of Rhizobium. Science 257:70-72.

Van den Eede, G., Dreyfus, B., Goethals, K., Van Montagu, M., and Holsters, M. 1987. Identification and cloning of nodulation genes from the stemnodulating bacterium ORS571. Mol. Gen. Genet. 206:291-299.

Van den Eede, G., Deblaere, R., Goethals, K., Van Montagu, M., and Holsters, M. 1992. Broad host range and promoter selection vectors for bacteria that interact with plants. Mol. Plant-Microbe Interact. 5:228234.

Verma, D. P. S., and Hong, Z. 1996. Biogenesis of the peribacteroid membrane in root nodules. Trends Microbiol. 4:364-368.

Vincent, J. M. 1970. A Manual for the Practical Study of the Root-Nodule Bacteria (IBP Handbook No. 15). Blackwell Scientific Publications, Oxford.

Yang, W.-C., de Blank, C., Meskiene, I., Hirt, H., Bakker, J., van Kammen, A., Franssen, H., and Bisseling, T. 1994. Rhizobium Nod factors reactivate the cell cycle during infection and nodule primordium formation, but the cycle is only completed in primordium formation. Plant Cell 6:1415-1426 